\title{
Blocking the eIF2 $\alpha$ Kinase (PKR) Enhances Positive and Negative Forms of Cortex-Dependent Taste Memory
}

\author{
Elad Stern, ${ }^{1 \star}$ Adaikkan Chinnakkaruppan, ${ }^{1 \star}$ Orit David, ${ }^{1}$ Nahum Sonenberg, ${ }^{2}$ and Kobi Rosenblum ${ }^{1}$ \\ ${ }^{1}$ Sagol Department of Neurobiology, Center for Gene Manipulation in the Brain, University of Haifa, Mount Carmel, Haifa 39105, Israel, and ${ }^{2}$ Department of \\ Biochemistry and the Goodman Cancer Center, McGill University, Montreal, Quebec H3A 1Y3, Canada
}

\begin{abstract}
Age-associated memory deterioration (and the decline in ability to acquire new information) is one of the major diseases of our era. Cognitive enhancement can be achieved by using psycho-stimulants, such as caffeine or nicotine, but very little is known about drugs that can enhance the consolidation phase of memories in the cortex, the brain structure considered to store, at least partially, long-term memories. We used cortex-dependent taste-learning paradigms to test the hypothesis that pharmacological manipulation of the translation initiation eIF $2 \alpha$, which plays a role in hippocampus-dependent memory, can enhance positive or negative forms of taste memories. We found that dephosphorylation (Ser51) of eIF2 $\alpha$, specifically in the cortex, is both correlated with and necessary for normal memory consolidation. To reduce eIF $2 \alpha$ phosphorylation and improve memory consolidation, we pharmacologically inhibited one of the eIF $2 \alpha$ kinases, PKR, which is known to be involved in brain aging and Alzheimer's disease. Systemic or local microinjection of PKR inhibitor to the gustatory cortex enhanced both positive and negative forms of taste memory in rats and mice. Our results provide clear evidence that PKR plays a major role in cortex-dependent memory consolidation and, therefore, that pharmacological inhibition of PKR is a potential target for drugs to enhance cognition.
\end{abstract}

\section{Introduction}

Sensory information in the mammalian brain is encoded, at least in part, in the relevant cortical area, but very little is known about pharmacological manipulations that could facilitate cortically dependent learning.

From the temporal perspective, a given memory involves acquisition, consolidation, and retention phases, possibly followed by many cycles of relearning, reconsolidation, and reretention (for review, see Dudai, 2004; Alberini et al., 2006; Nader and Hardt, 2009; Alberini, 2011; Johansen et al., 2011). Memory consolidation, a process in which labile short-term memories are transformed over time into stable long-term memories, is divided into system and molecular consolidation; however, the connection between the two is not clear (Gildish et al., 2012). System consolidation is defined by the time frame in which a given brain structure (e.g., the hippocampus) is indispensable for normal memory retention, and is a very slow dynamic process (Johansen et al., 2011). Molecular consolidation is biochemically defined by the time frame in which pharmacological perturbations (e.g., by protein synthesis inhibitors) attenuate long-term but not shortterm memories.

Received May 14, 2012; revised Dec. 3, 2012; accepted Dec. 4, 2012.

Author contributions: E.S. and K.R. designed research; E.S., A.C., and 0.D. performed research; N.S. contributed unpublished reagents/analytic tools; E.S., A.C., 0.D., and K.R. analyzed data; A.C., N.S., and K.R. wrote the paper.

This work was supported by ISF (Grant 1305/08), Morasha-ISF, and DIP (Grant DFG-DIP R03971/1-1) to K.R. We thank Professor Orna Elroy-Stein (Tel Aviv University) for the elF2 $\alpha \mathrm{Ab}$.

The authors declare no competing financial interests.

*E.S. and A.C. contributed equally to this work.

Correspondence should be addressed to Dr. Kobi Rosenblum, Department of Neurobiology, Center for Gene Manipulation in the Brain, University of Haifa, Mt. Carmel, Haifa, 31905, Israel. E-mail: kobir@psy.haifa.ac.il.

DOI:10.1523/JNEUROSCI.2322-12.2013

Copyright $\odot 2013$ the authors $\quad 0270-6474 / 13 / 332517-09 \$ 15.00 / 0$
Recently, several studies, based on differing behavioral paradigms susbserved by different brain structures, demonstrated that molecular consolidation is mediated through complex regulation of mRNA translation (for reviews, see Costa-Mattioli et al., 2009a, b; Gkogkas et al., 2010; Gal-Ben-Ari and Rosenblum, 2011). As reviewed extensively (Sonenberg and Hinnebusch, 2009), translation regulation occurs during both the initiation and the elongation phases, and both phases are regulated during memory consolidation (Banko et al., 2005, 2007; Belelovsky et al., 2005; Costa-Mattioli et al., 2005, 2007; Antion et al., 2008a, b; Banko and Klann, 2008; Jiang et al., 2010; Hoeffer et al., 2011; Gildish et al., 2012). In addition, several signal transduction cascades regulate different components of the translation machinery during memory consolidation (Belelovsky et al., 2009; Johansen et al., 2011; Gal-Ben-Ari and Rosenblum, 2012). One of the wellexplored events that control translation initiation is Ser51 phosphorylation of the initiation factor $2 \alpha$ (eIF2 $\alpha$ ) (Hinnebusch, 2000; Dever, 2002; Sonenberg and Dever, 2003). eIF2 $\alpha$ phosphorylation results in impaired translation of most mRNAs but paradoxically increases translation of mRNAs harboring several initiation sites on the 5' UTR, such as ATF4 and BACE1 (Harding et al., 2000; Vattem and Wek, 2004; O'Connor et al., 2008). Phosphorylation levels of eIF $2 \alpha$ inhibits the transformation of shortto long-term synaptic plasticity and memory (Costa-Mattioli et al., 2007). eIF $\alpha$ can be phosphorylated by four well-described kinases- double-stranded RNA-dependent protein kinase (PKR), PKR-like endoplasmic reticulum kinase (PERK), amino acidsregulated eIF2 $\alpha$ kinase (GCN2), and heme-regulated eIF2 $\alpha$ kinase and is dephosphorylated by PP1 and GADD34 (for a recent review, see Gkogkas et al., 2010). Malfunction of PKR is known to be involved in Alzheimer's, Parkinson's, and Huntington's dis- 
eases, aging-related cognitive decline, and hippocampusdependent learning (Peel et al., 2001; Peel and Bredesen, 2003; Bando et al., 2005; Paquet et al., 2009; Couturier et al., 2010; Zhu et al., 2011); therefore, PKR involvement in cortex-dependent memory consolidation is of a prime target. To this end, we used the well-studied system of insular-cortex-dependent taste learning and memory (Yefet et al., 2006; Elkobi et al., 2008; Rosenblum, 2008; Gal-Ben-Ari and Rosenblum, 2012).

\section{Materials and Methods}

Animals

Male Wistar Hola rats weighing 200-250 g were procured from Harlan, provided ad libitum with standard commercial rat chow and water, and were maintained on a 12/12 h light/dark cycle. Experiments were approved by the Institutional Animal Care and Use Committee of Haifa University, and adequate measures were taken to minimize pain or discomfort, in accordance with the guidelines laid down by the European Union and the United States National Institutes of Health, regarding the care and the use of animals for experimental procedures.

\section{Behavioral procedures}

Novel-taste learning. The rats were separated into individual housing cages and underwent a 3-day water-restriction training session, in which, once a day for $20 \mathrm{~min}$, they were offered $20 \mathrm{ml}$ of water from two pipettes, each containing $10 \mathrm{ml}$. On the fourth day, the control group received water and the experimental group was exposed to a novel taste $(0.1 \%$ (w/v) sodium saccharin) (Rosenblum et al., 1993). After two successive days of water-restriction training, the rats were tested in a multiplechoice test involving two pipettes of water and two of saccharin. The behavioral data are presented in terms of preference index, expressed as a percentage, $[\mathrm{ml}$ saccharin $/(\mathrm{ml}$ water plus $\mathrm{ml}$ saccharin $)] \times 100$, in which the quantities are those consumed during each test.

Conditioned taste aversion. Conditioned taste aversion (CTA) was performed as described previously (Rosenblum et al., 1993; BarkiHarrington et al., 2009). The rats were trained for $3 \mathrm{~d}$ to drink from pipettes during 20 min periods, similarly to the novel taste learning procedure. On the conditioning (i.e., fourth) day, they were allowed to drink the saccharin solution (CS), containing $0.1 \%$ sodium saccharin, instead of water, from similar pipettes, for $20 \mathrm{~min}$, and $40 \mathrm{~min}$ later they were injected with 0.05 or $0.15 \mathrm{~m} \mathrm{LiCl}$ solution (US) at $2 \%$ of body weight. After two successive days of training, the rats were tested in a multiplechoice test involving two pipettes of water and two of saccharin. The behavioral data are presented in terms of aversion index, expressed as a percentage, $[\mathrm{ml}$ water $/(\mathrm{ml}$ water plus $\mathrm{ml}$ saccharin $)] \times 100$, in which the quantities are those consumed during each test. The greater the rats' preference for water over the conditioned novel taste, the higher the aversion index and, therefore, the better the memory.

Latent inhibition. The latent inhibition (LI) paradigm was combined with CTA to isolate the effect of taste learning from the potentially confounding effects of the US and the association of CS-US. The LI of CTA was performed as described previously (Rosenblum et al., 1993; BarkiHarrington et al., 2009). Animals in LI were preexposed to the novel taste $2 \mathrm{~d}$ before the CTA experiment, thereby significantly reducing their acquired aversion. Testing was performed as described above for CTA.

\section{Hippocampal slice preparation}

After decapitation, the brain was immediately immersed in cold $\left(4^{\circ} \mathrm{C}\right)$ carboxygenated $\left(95 \% \mathrm{O}_{2}, 5 \% \mathrm{CO}_{2}\right)$ artificial cerebrospinal fluid, which comprised $124 \mathrm{~mm} \mathrm{NaCl}, 5 \mathrm{~mm} \mathrm{KCl}, 1.2 \mathrm{~mm} \mathrm{MgSO}_{4}, 1.2 \mathrm{~mm} \mathrm{NaH}_{2} \mathrm{PO}_{4}$, $26 \mathrm{~mm} \mathrm{NaHCO}_{3}, 10 \mathrm{~mm}$ D-glucose, and $2.4 \mathrm{~mm} \mathrm{CaCl}_{2}$. After $\sim 2 \mathrm{~min}$, both hippocampi were dissected out in a plate filled with cold $\left(4^{\circ} \mathrm{C}\right)$ artificial cerebrospinal fluid on ice. The hippocampi were then put on a cooled stand of a McIlwain tissue chopper TC752 (Campden Instruments), cut into $400 \mu \mathrm{m}$ slices, and then put back into a chamber filled with cold $\left(4^{\circ} \mathrm{C}\right)$ carboxygenated artificial cerebrospinal fluid (see Kaphzan et al., 2006,2007 for more details).

The hippocampal slices were kept in six different chambers at room temperature for $2 \mathrm{~h}$ before any pharmacological intervention; each chamber contained four slices. Within each experiment, two chambers

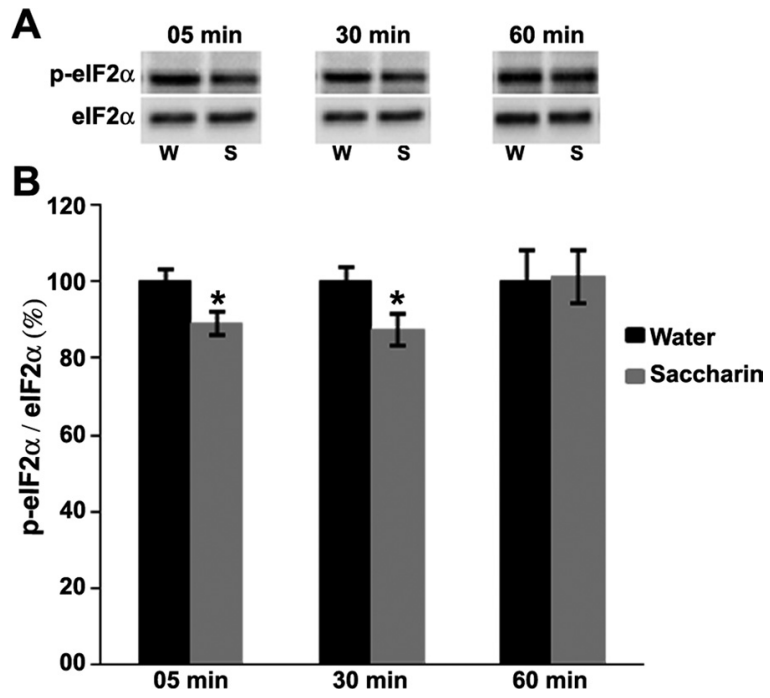

Figure 1. Novel taste learning induces dephosphorylation of elF2 $\alpha$ (Ser51) in the gustatory cortex. $\boldsymbol{A}$, Representative immunoblots from the gustatory cortex, 5, 30, and $60 \mathrm{~min}(n=10,6$, and 6, respectively) after exposure to saccharin (S; novel taste) or water (W; familiar taste). $\boldsymbol{B}$, elF2 $\alpha$ phosphorylation is expressed as the ratio between antiphosphospecific (Ser51) antibody and antiprotein antibody. Results were normalized to rats that consumed the same amount of water $\left(t\right.$ test): ${ }^{*} p<0.05$. Data are mean \pm SEM.

were used as a positive control for the quality of the slices, by infusing the chambers with $0.5 \%$ DMSO in saline, and the remaining four chambers were the experimental chambers. PKR inhibitor (PKRi; catalog \#527450; Calbiochem) was dissolved in DMSO and further diluted in saline to a final DMSO concentration of $0.5 \%$. Each chamber was incubated with the $50 \mu \mathrm{M}$ PKRi for the indicated time intervals ( $30 \mathrm{~min}$ to $4 \mathrm{~h}$ ).

\section{Cannulation, sal003 and PKRi}

The rats were cannulated according to Barki-Harrington et al. (2009). Briefly, the rats were anesthetized by administration, at $0.3 \mathrm{ml} / 100 \mathrm{~g}$, of equithesin, comprising: $2.12 \%(\mathrm{w} / \mathrm{v}) \mathrm{MgSO}_{4}, 10 \%$ (v/v) ethanol, $39.1 \%$ (v/v) propyleneglycol, $0.98 \%(\mathrm{w} / \mathrm{v})$ sodium pentobarbital, and $4.2 \%$ $(\mathrm{w} / \mathrm{v})$ chloral hydrate. They were restrained in a sterotactic frame (Steolting) and stainless steel guide cannulae (23 gauge) were bilaterally implanted into the gustatory cortex, angled at (with reference to bregma): anteroposterior $=+1.2 \mathrm{~mm}$, lateral $= \pm 5.5 \mathrm{~mm}$, and ventral $=+5.5$ $\mathrm{mm}$. Two skull screws were inserted into the skull, and acrylic dental cement was applied to secure the cannulae in position. A 28 gauge stylus was inserted into each guide cannula to prevent clogging. The rats were allowed a week in individual cages to recover from the surgery, before the experimental manipulation.

Sal003 was dissolved in DMSO and further diluted in saline to a final DMSO concentration of $0.1 \%$. PKRi was dissolved in DMSO and further diluted in saline to a final DMSO concentration of $0.5 \%$. A total of $1 \mu \mathrm{l}$ of $50 \mu \mathrm{M}$ PKRi or vehicle was infused bilaterally.

For microinfusion, the stylus was removed from the guide cannula and a 28 gauge injection cannula was carefully inserted, to extend $1.0 \mathrm{~mm}$ beyond the tip of the guide cannula. The injection cannula was connected via PE20 tubing to a Hamilton syringe (Hamilton) driven by a CMA/100 microinjection pump (Carnegie Medicin), to provide an injection rate of $1 \mu \mathrm{l} / \mathrm{min}$. After $1 \mathrm{~min}$ of infusion, the injection cannula was kept in the guide cannula for an additional minute to minimize dragging of infused solutes along the injection tract. Locations of cannula were verified in 30 $\mu \mathrm{m}$ coronal sections.

\section{Preparation of total samples for biochemical analysis}

At the end of the behavioral procedure, the brain was removed, gustatory cortex and/or hippocampus tissue was dissected and homogenized in a glass-Teflon homogenizer in a lysis buffer containing $10 \mathrm{~mm}$ HEPES, $\mathrm{pH}$ 7.4, 2 mм EDTA, 2 mм EGTA, 0.5 mm DTT, 1\% phosphatase inhibitor mixture (Sigma), and $1 \%$ protease inhibitor mixture (Sigma). Protein 
A

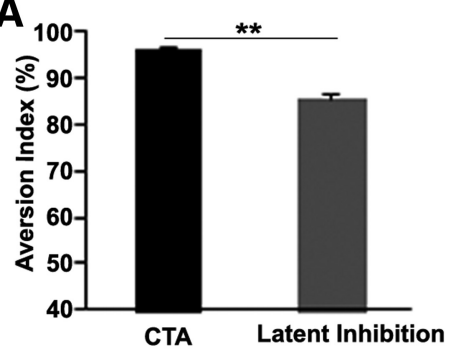

B

C

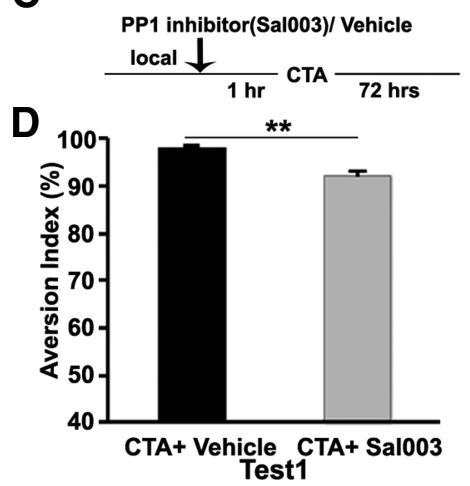

$\mathbf{F}$
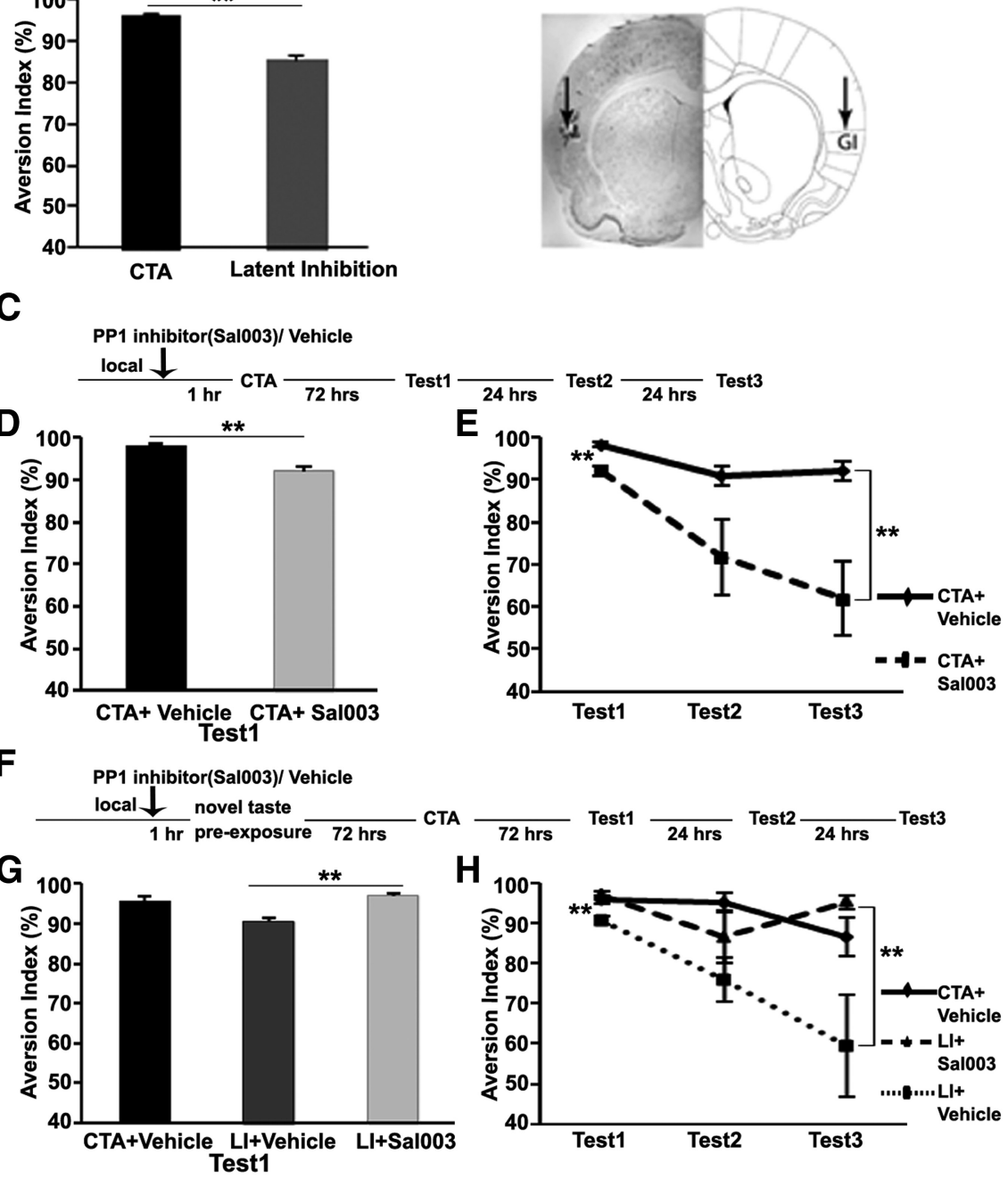

$\mathbf{H}$

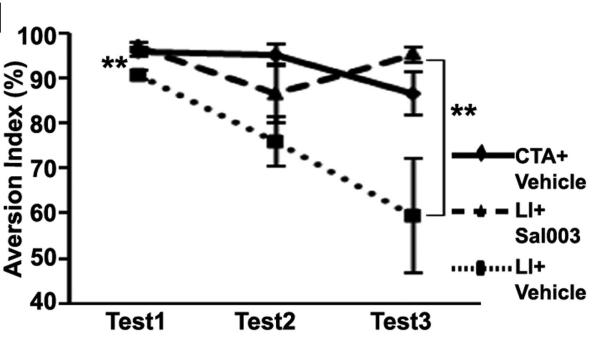

Figure 2. elF2 $\alpha$ dephosphorylation (Ser51) is necessary for long-term taste memory. $\boldsymbol{A}, \mathrm{A}$ typical result of CTA and LI of CTA experiments. LI rats show lower aversion rates than CTA rats $(n=9) .{ }^{* *} p<0.001$. B, A representative slice with Nissl staining shows the position of the cannula and the injection site. GI, Granular insular cortex. $C$, Outline of behavioral procedures designed to examine the hypothesis that reduction of the phosphorylation level of elF2 $\alpha$ is necessary for CTA. D, PP1 inhibitor (Sal003) microinfusion $1 \mathrm{~h}$ before CTA results in a lower aversion index for saccharin on the first test day $(n=5)$. ${ }^{* *} p<0.01$. E, Microinjection of Sal003 $1 \mathrm{~h}$ before CTA results in lower aversion rate for saccharin than in vehicle-injected rats for three consecutive test days $(n=5) .{ }^{* *} p=0.01 . \boldsymbol{F}$, Outline of behavioral procedure designed to examine the hypothesis that reduction of the phosphorylation level of elF $2 \alpha$ is necessary for long-term taste memory. G, Local application of PP1 inhibitor, Sal003 into the GC $1 \mathrm{~h}$ before novel-taste before exposure results in higher aversion levels, similar to those in the CTA group and different from those in the vehicle group $(n=5) .{ }^{* *} p<0.01$. $\boldsymbol{H}$, Microinjection of Sal003 into the $\mathrm{GC} 1 \mathrm{~h}$ before novel taste before exposure results in higher saccharin aversion rate than in vehicle-injected rats for three consecutive test days $(n=5) .{ }^{* *} p<0.01$. Data are mean \pm SEM.

content was determined with a Bradford Assay Kit (Bio-Rad) or a BCA Protein Assay Kit (GE Healthcare). Appropriate volumes of $2 \times$ SDS sample buffer (10\% glycerol, $5 \% \beta$-mercaptoethanol, $4 \%$ SDS, $120 \mathrm{~mm}$ Tris- $\mathrm{HCl}, \mathrm{pH}$ 6.8) were added to the homogenates, and samples were boiled for $5 \mathrm{~min}$ and stored at $-20^{\circ} \mathrm{C}$ pending further analysis.

\section{Subcellular fractionation}

The rats were decapitated, their brains were rapidly removed, and the insular cortex and the hippocampus were dissected immediately and frozen in liquid nitrogen. The subcellular fractions were prepared as described previously (Huttner et al., 1983; Schumann and Yaka, 2009). Briefly, brain tissues were homogenized $(\mathrm{H})$ in ice-cold homogenization buffer (10 mm Tris-HCl, pH 7.4, 1 mм EDTA, 1 mм EGTA, 320 mм sucrose, protease inhibitor mixture, Sigma; and phosphatase inhibitor mixture, Sigma); the homogenates were rested on ice for $20 \mathrm{~min}$ and then centrifuged at $1000 \times g$ for $5 \mathrm{~min}$ at $4^{\circ} \mathrm{C}$ to remove nuclei and large debris
(P1). The supernatant (S1) was centrifuged at $10,000 \times g$ for $30 \mathrm{~min}$ at $4^{\circ} \mathrm{C}$ in a conventional Eppendorf centrifuge to obtain a crude synaptosomal fraction (P2), and subsequently lysed hypo-osmotically and centrifuged at 25,000 $\times$ $g$ in a Beckman Coulter ultracentrifuge at $4^{\circ} \mathrm{C}$ for $2 \mathrm{~h}$, to pellet a synaptosomal membrane fraction (LP1). The resulting supernatant (LS1) was centrifuged at $165,000 \times g$ for $2 \mathrm{~h}$ at $4^{\circ} \mathrm{C}$ to obtain a synaptic vesicle-enriched fraction (LP2). The supernatant (S2) obtained from the fraction P2 was centrifuged at $165,000 \times g$ for $2 \mathrm{~h}$ to obtain a cytosolic fraction (supernatant; S3) and a light membrane fraction (pellet; P3). To avoid possible crossover contamination, the pellet that resulted from each centrifugation was rinsed briefly with ice-cold homogenization buffer before being subjected to subsequent fractionations. Protein content was determined with the BCA Protein Assay Kit (GE Healthcare).

\section{Western blotting}

Samples were prepared in SDS sample buffer, subjected to 7.5-10\% SDS-PAGE and Western blot analysis. Each lane was loaded with the same amount of proteins. After transfer to a nitrocellulose membrane, the blots were blocked for $1 \mathrm{~h}$ with $4 \%$ BSA in Tris-buffered saline plus $0.5 \%$ Tween 20 (TBST) at room temperature. They were then incubated overnight with the primary antibodies $\mathrm{p}(\mathrm{Thr} 451) \mathrm{PKR}(1$ : 1000; MBL), eIF2 $\alpha$ (1:500; a kind gift from Prof. Orna Elroy-Stein, of Tel Aviv University), p(Ser51)eIF2 $\alpha$ (1:1000; Cell Signaling Technology), and p(Ser52)eIF2 $\alpha$ (1:500; MBL), GCN2, PERK, ERK, p(Thr202/Tyr204)ERK (1:1000) and S6K1 (1:1000) (Cell Signaling Technology), PSD-95 (1:1000), PKR (1:1000), and $\beta$-actin (1: 3000) (Santa Cruz Biotechnology), and $\beta$-tubulin $(1: 30,000)$ (Sigma). The blots were then subjected to three 5 min washing steps in TBST, after which they were incubated with the corresponding HRP-conjugated secondary antibodies: goat anti-rabbit (IgG), goat anti-mouse (IgG), or rabbit anti-goat (IgG) $(1: 10,000)$ (Millipore Bioscience Research Reagents), for $1 \mathrm{~h}$ at room temperature followed by three $10 \mathrm{~min}$ washes with TBST. Immunodetection was performed with the enhanced-chemiluminescence EZ-ECL Kit (Biological Industries).

The immunoblots were quantified with a CCD camera and Quantity One software (Bio-

Rad). Each sample was measured relative to the background. Phosphorylation levels were calculated as the ratio between the readings from the antibody directed against the phosphoproteins and those from the antibody directed against the phosphorylation-stateindependent forms of the proteins.

\section{Experiments in mice}

Mice were maintained on a 12/12 h light/dark cycle with food and water ad libitum. Male and female homozygous PKR mutants and control wildtype (WT) littermates were obtained in the $129 \mathrm{SvEv}$ background (Abraham et al., 1999). Genotyping was carried out by PCR analysis, with DNA obtained from tail biopsies on postnatal day 21, the day of weaning. Three- to four-month-old mice were used for the experiments. All experiments were performed in accordance with the regulations of the Institutional Animal Care and Use Committee of Haifa University.

Behavioral experiments in mice. Inherent aversion to bitter taste was examined to address the taste perception in $\mathrm{PKR}^{-1-}$ mice. After $3 \mathrm{~d}$ of 
water-restriction training sessions, in which the mice were offered $10 \mathrm{ml}$ of water from two pipettes, each containing $5 \mathrm{ml}$, once a day for $20 \mathrm{~min}$, they were offered four pipettes simultaneously: two containing $5 \mathrm{ml}$ of $0.04 \%$ quinine (Fluka) each, the other two containing $5 \mathrm{ml}$ of water each. The aversion index was determined as described above.

The detailed methods of CTA and LI were described by Gildish et al. (2012). Briefly, novel-taste learning, CTA, and LI experiments were conducted very similarly to those described above for the rats, except that the CS was $0.5 \%$ saccharin or $0.4 \% \mathrm{NaCl}$. The concentration of $\mathrm{LiCl}$ as a US was $0.05 \mathrm{M}$ for weak or $0.14 \mathrm{M}$ for strong protocols.

Statistical analysis. Data are expressed as mean \pm SEM. Statistical analysis was conducted with Student's $t$ test, one-way ANOVA, and repeatedmeasures ANOVA, as appropriate. Statistical analysis was performed with an $\alpha$ level of 0.05 .

\section{Results}

Novel taste learning induces dephosphorylation of eIF $2 \alpha$ (Ser51) in the gustatory cortex

To examine the effect of novel-taste ( $0.1 \%$ saccharin solution) learning on the phosphorylation state of $\operatorname{eIF} 2 \alpha$, we collected the gustatory cortex (GC) of rats at several time points after taste learning. Western blotting analysis revealed that incidental taste learning resulted in an immediate small but significant dephosphorylation of eIF $2 \alpha$ on Ser51, which was observed shortly after exposure to a novel taste (i.e., 5 and $30 \mathrm{~min}$ from the end of the drinking period) $\left(t\right.$ test: $t_{(18)}=2.65 ; p<0.02$ and $t$ test: $t_{(10)}=$ $2.27 ; p<0.05$, respectively). Sixty minutes after the learning, the p-eIF $2 \alpha$ level returned to its base value (Fig. 1). These results show a correlation between novel-taste learning and decreased phosphorylation of eIF $2 \alpha$ in the GC.

\section{Reduction in eIF2 $\alpha$ (Ser51) phosphorylation is necessary for long-term taste memory}

Following the observation that eIF $2 \alpha$ dephosphorylation correlates with taste learning in the GC, we asked whether eIF $2 \alpha$ phosphorylation in the GC was necessary for taste-memory consolidation. First, we standardized behavioral protocols and the cannulation procedure and injection system to locally inhibit the activity of appropriate proteins. Figure $2 A$ shows the strength of CTA and LI memory. LI rats show lower aversion rates than CTA rats $(n=9$; $p<0.001)$. The representative figure indicating the guiding cannula placement and the injection site is shown in Figure $2 B$. Local microinjection of Sal003 $(1 \mu \mathrm{l}, 50 \mu \mathrm{M})$, a PP1 inhibitor, which serves as one of the eIF2 $\alpha$ phosphatases (Costa-Mattioli et al., 2007), into the GC $1 \mathrm{~h}$ before CTA resulted in a significant decrease of the aversion level compared with that in vehicle-injected rats on the first retrieval test day $(92.07 \pm 1.09$ for the Sal003 group vs $98.13 \pm 0.57$ for the vehicle group; $t$ test: $t_{(8)}, p<0.01$; Fig. 2D). Furthermore, aversion dropped rapidly during the three consecutive test days $(61.81 \pm 8.73$ for the Sal003 group vs $92.04 \pm 2.38$ for the vehicle group; $t$ test: $t_{(8)}, p<0.01$ at test day 3 ; repeated-measures ANOVA: $F_{(1,8)}=10.976, p<0.01$; Fig. $\left.2 E\right)$. To examine the necessity for eIF $2 \alpha$ dephosphorylation during the consolidation of novel-taste memory in the GC, we injected Sal003 directly into the GC $1 \mathrm{~h}$ before application of the LI paradigm (Fig. 2F). As expected from the two control groups, the vehicle-injected LI group showed a lower aversion than the vehicle-injected CTA group $(90.70 \pm 0.86$ vs $95.87 \pm 0.98$, respectively; $t$ test: $t_{(6)}, p<0.01$; Fig. $\left.2 G\right)$. However, the Sal003injected LI group showed higher aversion than the vehicleinjected LI group ( $96.99 \pm 0.77$ vs $90.70 \pm 0.86$, respectively; $t$ test: $t_{(8)}, p<0.01$; Fig. $2 G$ ), and their levels were similar to those of the vehicle-injected CTA group. Analysis of the three consecutive retrieval test days revealed a major group effect between the

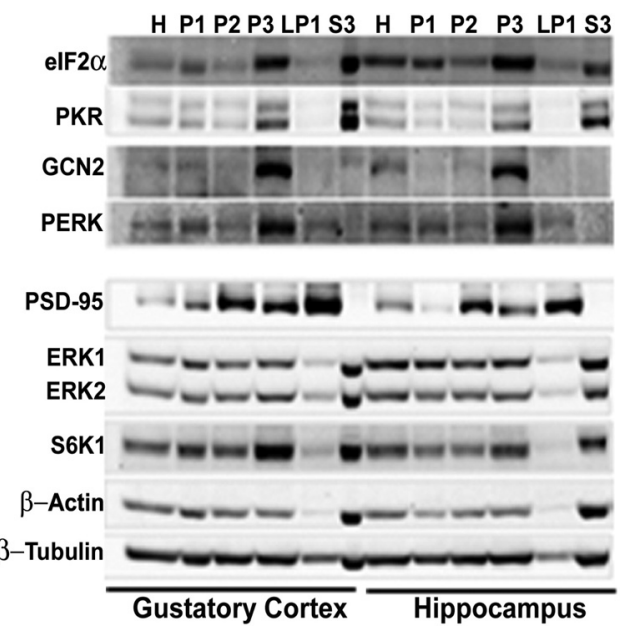

Figure 3. Distribution of elF $2 \alpha$ kinases in various fractions obtained from cortex and hippocampus. Adult naive rats were killed, GC and hippocampus tissues were dissected, and subcellular fractionation was performed as described in Materials and Methods. Representative immunoblots of the elF2 $\alpha$ kinases known to be present in the brain (PKR, GCN2, and PERK). elF2 $\alpha$ and its three kinases are abundantly present in the light membrane (P3) fraction; however, both elF2 $\alpha$ and PKR are also expressed in relative high amounts in the cytosolic fraction (S3). Representative immunoblots of known synaptic and plasticity markers are shown $(n=4)$. Synaptic protein PSD-95 is abundantly observed in crude synaptosomal (P2) and synaptosomal membrane fractions (LP1).

Sal003-injected and the vehicle-injected LI animals (mixed model repeated-measures ANOVA: $F_{(2,10)}=7.711, p<0.01 ;$ post hoc analysis, Bonferroni test: Sal003 vs LI, $p=0.015$; Fig. $2 H$ ). These results demonstrate that eIF2 $\alpha$ dephosphorylation in the GC is both correlative and necessary for positive (LI paradigm) as well as negative (CTA) forms of taste learning.

\section{PKRi decreases PKR (Thr451) and eIF2 $\alpha$ (Ser51) phosphorylation in hippocampal slices}

Because eIF $2 \alpha$ dephosphorylation in the GC is both correlative and necessary for taste learning, we hypothesized that inhibiting one of the eIF $2 \alpha$ kinases that are expressed in the brain would facilitate taste memory. Three eIF2 $\alpha$ kinases (i.e., PKR, GCN2, and PERK) are similarly expressed in the brain (Fig. 3). Synaptic marker and synaptic plasticity related proteins are also shown in Figure 3. In the present study, we investigated PKR. First, to study the effect of PKRi (Jammi et al., 2003) on brain tissue from the adult rat, we analyzed its effect on hippocampal slices and found that it decreased PKR phosphorylation dramatically at Thr 451 after $0.5 \mathrm{~h}(0.26 \pm 0.12$ for C-16 group vs $1.00 \pm 0.04$ for the vehicle group; $t$ test: $t_{(9)}, p<0.01$; Fig. $4 A$ ). The phosphorylation of PKR remained low during the first $3 \mathrm{~h}$ after PKRi application and returned to its base level after $4 \mathrm{~h}$, whereas eIF2 $\alpha$ phosphorylation was affected more slowly and was significantly lower only after $2 \mathrm{~h}$ after PKRi application to the hippocampal slices $(0.68 \pm 0.06$ for the $\mathrm{C}-16$ group vs $1.00 \pm 0.08$ for the vehicle group; $t$ test: $t_{(9)}, p<0.05$; Fig. $\left.4 A\right)$. PKRi did not affect the phosphorylation levels of either ERK2 or S6K1 ( $p>0.05$; Fig. $4 B$ ), indicating that it did not perturb two major signaling pathways known to be necessary for taste-memory consolidation (Ingrand et al., 2007). Furthermore, PKRi did not change the $\beta$-actin or $\beta$-tubulin levels in hippocampal slices ( $p>0.05$; Fig. $4 C)$.

\section{Systemic application of PKRi enhances both CTA and novel taste learning}

We tested the hypothesis that inhibition of PKR would enhance cortex-dependent taste memory. A weak CTA protocol, which was induced with a weak US (i.e., $0.05 \mathrm{M} \mathrm{LiCl}$ instead of $0.15 \mathrm{M} \mathrm{LiCl}$ ), 
A

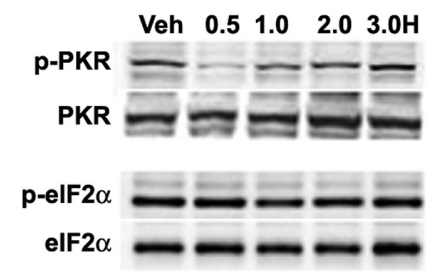

B

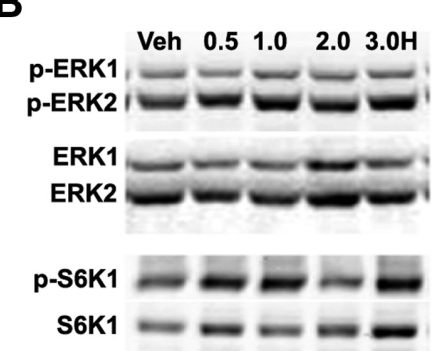

C

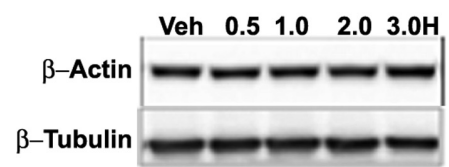

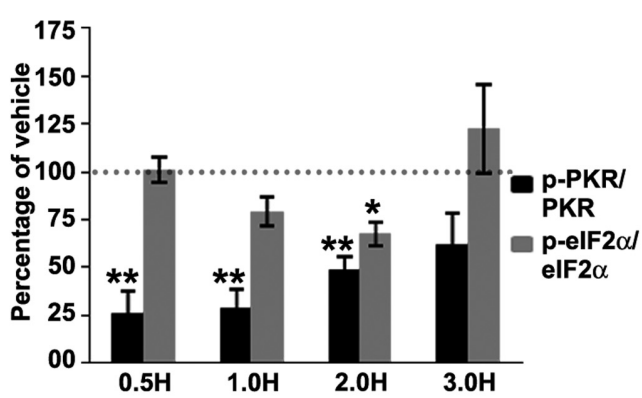
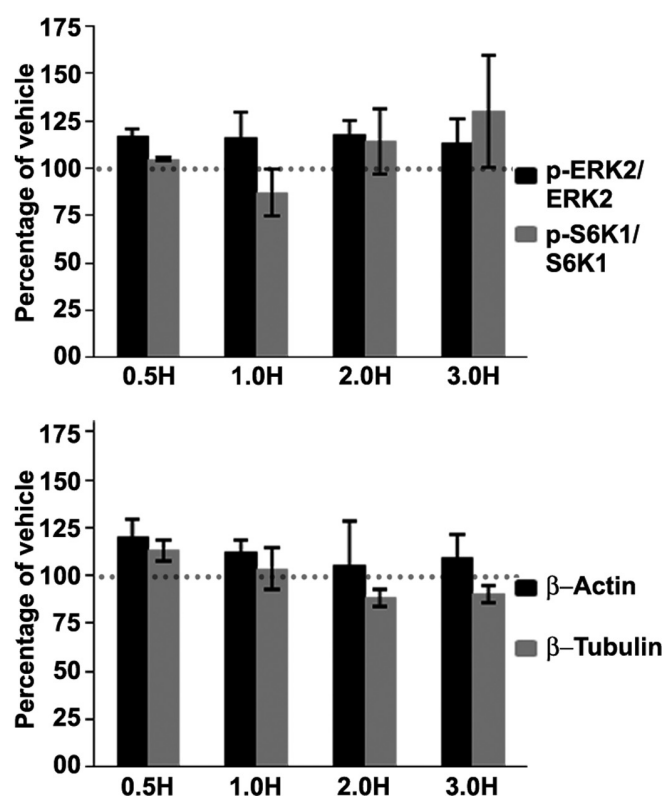

Figure 4. PKRi decreases phosphorylation of PKR (Thr451) and elF2 $\alpha$ (Ser51) in hippocampal slices. A, Hippocampal slices were incubated with PKRi or vehicle containing $0.5 \%$ DMSO for $0.5,1,2$, or $3 \mathrm{~h}$. Protein phosphorylation is expressed as the ratio between antiphosphospecific antibody and antiprotein-directed antibody, normalized to vehicle values. Left panels of the bar graphs are representative immunoblots. Phosphorylation of PKR on Thr451 diminished $0.5-3 \mathrm{~h}$ after application of $50 \mu \mathrm{m}$ PKRi relative to the level in the vehicle-exposed group $(n \geq 4) .{ }^{*} p<0.05 .{ }^{* *} p<0.01$. elF2 $\alpha$ phosphorylation on Ser51 also decreased $2 \mathrm{~h}$ after PKRi application $(n \geq 4) .{ }^{*} p<0.05$. B, PKRi does not affect other important pathways of translational control. ERK2 and $56 \mathrm{~K} 1$ phosphorylation is not changed $0.5-3 \mathrm{~h}$ after application of 50 $\mu \mathrm{M}$ PKRi relative to vehicle-exposed group $(n \geq 4) . p>0.05$. C, PKRi does not affect the levels of $\beta$-actin or $\beta$-tubulin compared with vehicle exposure. Data are mean \pm SEM.

resulted in a significantly lower aversion index than that induced by a strong CTA (repeated-measures ANOVA: $F_{(1,10)}=33.564, p<$ 0.01 ; Fig. $5 A$ ). Systemic application of PKRi did not change the body weight or the normal drinking behavior of rats (data not shown). Injection of PKRi (i.p.) $2 \mathrm{~h}$ before weak CTA acquisition resulted in a higher aversion index than that in the vehicle-injected group $\left(75.76 \pm 4.57\right.$ vs $53.26 \pm 6.81$, respectively, in Test 1 ; $t$ test: $t_{(14)}, p<$ 0.05 ; Fig. $5 B$ ). Moreover, in Test 2 , the aversion levels did not decrease in the PKRi-injected group, as they did in the vehicle-injected group. To evaluate positive taste learning, we used a taste preferences test, which indicates the decrease in the neophobia response, and therefore, the memory of a given taste, after increased familiarization (Gutiérrez et al., 2003). Intraperitoneal injection of the PKRi significantly elevated the preference index compared with vehicle injection (75.88 \pm 6.49 vs $48.63 \pm 4.86$, respectively; $t$ test: $t_{(10)}, p<0.01$; repeated-measures ANOVA: $F_{(1,10)}=8.069, p=0.018$; Fig. $5 C$ ), indicating that PKRi enhanced both negative and positive forms of cortex-dependent taste memory. These results demonstrate that intraperitoneal injection of PKRi did not serve as an unconditioned stimulus. To determine whether the PKRi effect was constrained in time, we applied PKRi 5 min after the end of the drinking session. No changes in the preference rate compared with that in the vehicle-injected group were observed $(50.49 \pm 10.3$ vs $50.82 \pm 8.32$, respectively; $t$ test: $t_{(11)}, p>$ 0.05 ; repeated-measures ANOVA: $F_{(1,11)}=$ $0.001, p=0.972$; Fig. $5 D$ ), indicating that the PKRi effect had a relatively short time window.

Local application of PKRi into the GC enhances both CTA and novel taste learning

After the observation that the systemic administration of PKRi enhanced taste memory, we tested the hypothesis that local application of PKRi directly into the GC would enhance both positive (novel taste) and negative (CTA) taste memories. First, we tested whether the local microinjection of PKRi into the GC reduces eIF $2 \alpha$ phosphorylation levels; very similar to our hippocampal slice pharmacology, phosphorylation levels of eIF $2 \alpha$ were significantly reduced $30 \mathrm{~min}$ after local infusion of PKRi into the GC ( $t$ test: $p<0.05$; Fig. $6 A)$. Local application of PKRi directly into the GC 30 min before weak CTA enhanced the aversion index compared with that of the vehicle injected group on the second test day $(81.96 \pm 5.12$ vs $49.91 \pm$ 12.22, respectively; $t$ test: $t_{(11)}, p<0.05$; Fig. $6 A$; repeated-measures ANOVA: $F_{(1,11)}=5.130, p<0.05$; Fig. $\left.6 B\right)$, demonstrating that PKR deactivation specifically in the GC was sufficient to enhance the negative form of taste memory. PKRi microinjection into the GC did not change the normal drinking behavior (data not shown). Therefore, the enhancement of weak CTA by microinjection of PKRi into the GC is additional evidence that PKRi enhances CTA by blocking PKR activity in the cortex, and not by other peripheral mechanisms. In addition, we tested the hypothesis that local application of PKRi into the GC would enhance taste memory per se: we injected the PKRi directly into the GC 30 min before applying the positive taste-learning paradigm. On the first retrieval test day, we found a significant increase in the preference index of the PKRi-injected group compared with that of the vehicle-injected group (85.27 \pm 3.56 vs $67.01 \pm 6.38$, respectively; $t$ test: $t_{(13)}, p<0.05$; Fig. $6 C)$. There was also a significant group effect between the PKRi- and the vehicle-injected animals (repeated-measures ANOVA: $F_{(1,13)}=9.253, p<0.01$; Fig. $6 C$ ). These results support the hypothesis that inhibition of cortical PKR enhances positive as well as negative forms of taste memory consolidation.

PKRi enhances CTA and novel taste learning specifically via PKR inhibition

To rule out the possibility that PKRi enhanced memory via another, unknown mechanism, we used $\mathrm{PKR}^{-/-}$mice (Abraham et al., 1999). Experiments were conducted to optimize the dose and 
the application time point (data not shown). Injection of the PKRi into wt mice 90 min before weak CTA resulted in significant elevation of the aversion index compared with the vehicle-injected group $(88.52 \pm 3.34$ vs $64.13 \pm 5.25$, respectively; $t$ test: $t_{(14)}, p<0.01$; repeated-measures ANOVA: $F_{(1,14)}=15.834, p<0.01$; Fig. $7 A)$. However, no such effect was found in PKR ko mice $(72.86 \pm 6.92$ vs $74.08 \pm$ 8.26, respectively; $t$ test: $t_{(18)}, p>0.05$; repeated-measures ANOVA: $F_{(1,18)}=$ 0.004, $p=0.95$; Fig. 7C). Furthermore, similar specific effects of the PKRi under the positive taste-learning paradigm were obtained with wt, but not with PKR ko mice. Whereas systemic application of the PKRi 90 min before positive novel taste learning in the wild-type mice resulted in significant elevation of the preference index compared with that of the vehicle-injected group (58.66 \pm 5.94 vs $33.87 \pm 7.15$, respectively; $t$ test: $t_{(15)}, p<0.05$; repeatedmeasures ANOVA: $F_{(1,15)}=5.146, p<0.05$; Fig. $7 B$ ), the same procedure elicited no greater effect on PKR ko mice than on vehicle-injected ones $(40.34 \pm 8.44$ vs $34.04 \pm 6.08$, respectively; $t$ test: $t_{(17)}$, $p>0.05$; repeated-measures ANOVA: $F_{(1,17)}=0.002, p=0.96$; Fig. $\left.7 C, D\right)$. These results demonstrate that PKRi enhanced cognition specifically via PKRdependent mechanisms.

Very similar to enhanced memory in hippocampus-dependent learning and memory tasks (Zhu et al., 2011), $\mathrm{PKR}^{-1-}$ mice showed significantly enhanced CTA memory ( $t$ test on Test $1 ; p<0.05$; repeated-measures ANOVA: $F_{(1,20)}=$ 5.502, $p<0.05$; Fig. $7 E)$. $\mathrm{PKR}^{-l-}$ mice demonstrated a normal taste perception as analyzed by the quinine taste avoidance (data not shown). However, unlike the effect of acute pharmacological inhibition of PKR on eIF $2 \alpha$ phosphorylation levels in hippocampal slices or in vivo, there is no notable difference in eIF $2 \alpha$ phosphorylation levels in GC ( $t$ test; $p=0.86$ ) or in hippocampus $(p=0.90)$ in $\mathrm{PKR}^{-1-}$ mice compared with that of wild-type controls (Fig. $7 F, G$ ).

\section{Discussion}

Our findings provide clear evidence that the inhibition of a double-stranded RNA-activated protein kinase PKR enhanced both the positive and the negative forms of taste learning and memory in both rats and mice.

Taste learning is a well-controlled behavior, which is frequently used to monitor nondeclarative memory and cognition in human and animal models (Gal-Ben-Ari and Rosenblum, 2011). Several phosphorylation events in the insular cortex are correlated with taste learning, including tyrosine phosphorylation of the 2B subunit of the NMDA receptor (Rosenblum et al., 1997; Barki-Harrington et al., 2009), various components of the translation machinery (Belelovsky et al., 2005, 2007, 2009). The reversible phosphorylation of eIF $2 \alpha$ on Ser51 is one of the key regulators at the level of translation initiation (Hinnebusch,
B
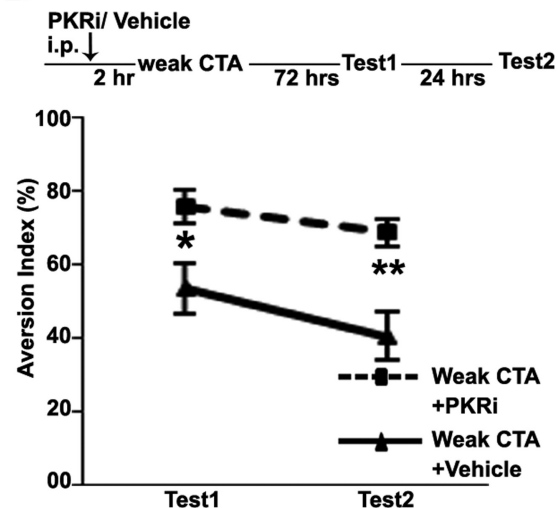

D
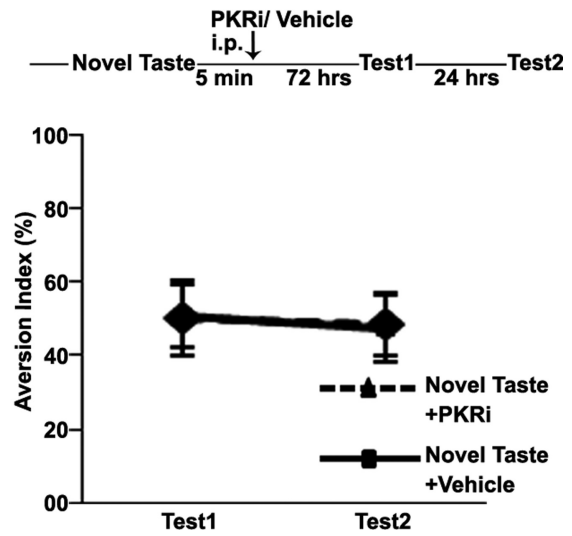

Figure 5. Systemic application (i.p. injection) of PKRi enhances both CTA and novel-taste learning in rats. $A$, Reduced concentration of $\mathrm{LiCl}(0.05 \mathrm{~m}$; weak CTA) was used instead of the normal concentration of $0.15 \mathrm{~m} \mathrm{LiCl}$ (strong CTA, which usually causes ceiling effect), to observe the strength of the aversive taste memory. B, Systemic injection (i.p.) of PKRi (at $167.5 \mu \mathrm{g}$ per $1 \mathrm{~kg}$ body weight) $2 \mathrm{~h}$ before weak exposure to novel taste enhances consumption of this taste compared with that by vehicle-injected rats $(n=6) .{ }^{* *} p<0.01$. D, Injection of PKRi (i.p.) 5 min after first exposure to novel taste does not affect consumption of this taste compared with that by vehicle-injected rats $(n \geq 6) . p=0.97$. Top diagrams, The behavioral procedures used. Data are mean \pm SEM.

2000; Dever, 2002; Sonenberg and Dever, 2003). Indeed, we found that novel-taste learning enhanced the dephosphorylation of eIF $2 \alpha$ on Ser51 in the GC of rats within $30 \mathrm{~min}$. At the same time, blocking dephosphorylation of eIF $2 \alpha$ indirectly through local application of Sal003 impaired both positive and negative forms of taste memory. Our findings are consistent with those of several previous studies that demonstrated that the dephosphorylation of eIF $2 \alpha$ was critical for long-term memory (LTM) (Costa-Mattioli et al., 2007; Jiang et al., 2010). In mutant eIF $2 \alpha^{+/ \text {S51A }}$ mice, which are heterozygous for the Serine51Alanine mutation, eIF $2 \alpha$ phosphorylation is reduced to $50 \%$ in the hippocampus, and formation of LTM was enhanced, as analyzed by a variety of behavioral tasks, including CTA and LI (Costa-Mattioli et al., 2007). In contrast, intrahippocampal injection of Sal003, a PP1 inhibitor that increases eIF2 $\alpha$ phosphorylation levels, immediately after training, impaired contextual fear memory in rats (Costa-Mattioli et al., 2007).

A large body of evidence also supports the hypothesis that lowering the levels of eIF $2 \alpha$ dephosphorylation is vital for synaptic plasticity, more specifically, for the induction of gene expression enabling L-LTP, which is correlated with learning and memory (Takei et al., 2001; Kelleher et al., 2004; Klann and Dever, 2004; Costa-Mattioli et al., 2005, 2007; Jiang et al., 
A

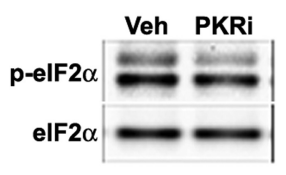

B
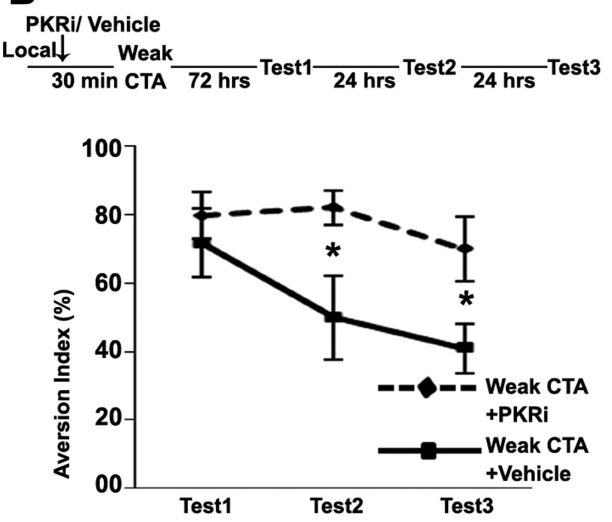

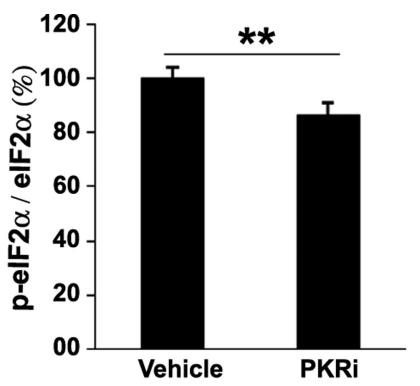

C
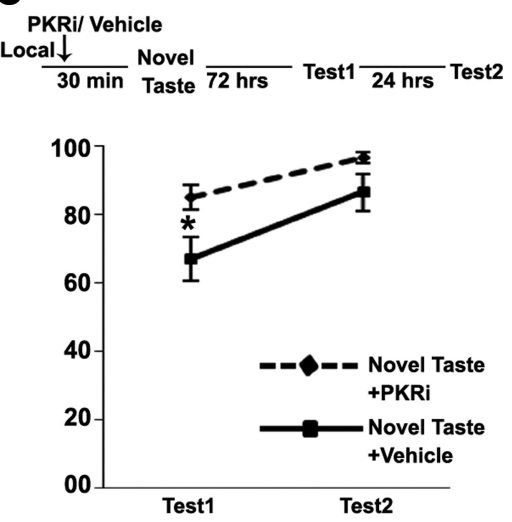

Figure 6. Local application of PKRi into the $\mathrm{GC}$ enhances both novel taste and CTA memory in rats. $\boldsymbol{A}$, Phosphorylation levels of elF2 $\alpha$ are reduced $(n \geq 11) 30$ min after local microinjection of PKRi (50 $\mu \mathrm{m} ; 1 \mu \mathrm{l})$ into the GC. ${ }^{*} p<0.05$. B. Microinfusion of PKRi $(50 \mu \mathrm{m}) 30 \mathrm{~min}$ before weak CTA results in higher aversion level than that in vehicle-injected rats $(n \geq 6){ }^{*} p<0.05$. C, Local application of PKRi 30 min before first exposure to novel taste enhances the consumption of this taste compared with that by vehicle-injected rats $(n \geq 7)$. ${ }^{*} p<0.01$. $\boldsymbol{B}, \boldsymbol{C}$, Top diagrams represent the behavioral procedures used. Data are mean $\pm \mathrm{SEM}$.

2010). Furthermore, the enhanced memory in $\operatorname{eIF} 2 \alpha^{+/ 551 \mathrm{~A}}$ mice was highly correlated with facilitated late-phase LTP (Costa-Mattioli et al., 2007). A recent study, in which PKRmediated phosphorylation of eIF $2 \alpha$ was specifically increased in hippocampal CA1 pyramidal cells in conditionally transgenic mice, demonstrated that the PKR-mediated increase in eIF2 $\alpha$ phosphorylation was sufficient to impair contextual fear memory and was correlated with impaired L-LTP (Jiang et al., 2010). Interestingly, eIF $2 \alpha$ phosphorylation was increased in ApoE4 mice, a model for sporadic Alzheimer's disease. These mice also showed contextual fear memory deficit compared with that of ApoE3 mice. Moreover, ApoE4 mice also showed increased phosphorylation of PKR in the hippocampus compared with APOE3 mice. Thus, increased eIF2 $\alpha$ phosphorylation impairs synaptic plasticity and LTM consolidation and positively correlated with PKR phosphorylation; therefore, inhibition of PKR could decrease eIF $2 \alpha$ phosphorylation and enhance memory consolidation, a hypothesis that we investigated further in taste-learning paradigms.

First, we found that, among the three major $\operatorname{eIF} 2 \alpha$ kinases expressed in the rat brain, eIF $2 \alpha$ and PKR were coexpressed abundantly in both light membrane and in cytosolic fractions, suggesting that PKR could effectively and locally regulate eIF2 $\alpha$ phosphorylation in the brain. PKRi specifically inhibited PKR phosphorylation and was correlated with the decreased eIF $2 \alpha$ phosphorylation. These findings are consistent with previous observations that PKRi did not act upon the mTOR, ERK, or S6K signaling cascades (Ingrand et al., 2007). Moreover, whereas PKRi improved taste memory in both rats and wild-type mice, it did not have any effect on long-term taste memory in PKR knock-out mice, which further indicates that the PKRi facilitates memory by specifically reducing PKR activity.
Application of PKRi reduced the eIF $2 \alpha$ phosphorylation in both hippocampal slices and in vivo; therefore, the eIF $2 \alpha$ phosphorylation-dependent pathway is one of the potential mechanisms that could link decreased PKR activity to enhanced learning and memory. Although increased eIF $2 \alpha$ phosphorylation inhibits general translation, it increases ATF4 (also known as CREB2) mRNA translation (Chen et al., 2003; Costa-Mattioli et al., 2007; Jiang et al., 2010), which is known to be a repressor of CREBdependent gene transcription, and the latter was reported to be essential for L-LTP and LTM formation, demonstrating that ATF4 is an important negative regulator of synaptic plasticity and memory (Bartsch et al., 1995; Chen et al., 2003). eIF $2 \alpha^{+/ 551 \mathrm{~A}}$ and $\mathrm{GCN} 2^{-1-}$ mice showed decreased ATF4 levels (Costa-Mattioli et al., 2005, 2007). Consistent with these data, a recent study demonstrated that activation of PKR in CA1 pyramidal cells enhanced eIF $2 \alpha$ phosphorylation and also increased ATF4 expression, which, in turn, suppressed CREB-dependent transcription/translation and thereby inhibited L-LTP and impaired contextual fear memory (Jiang et al., 2010). In addition, increasing eIF2 $\alpha$ phosphorylation via PKR activation failed to change the initiation phase of general translational machinery, which suggests that eIF $2 \alpha$ phosphorylation regulates the LTM through translational control of specific mRNAs (e.g., ATF4) (Jiang et al., 2010). Moreover, CREBdependent BDNF, c-fos, zif268, and c/EBP $\beta$ gene expressions were reduced after PKR activation (Jiang et al., 2010). Thus, enhanced taste memory observed after PKR inhibition could be mediated via eIF $2 \alpha$ phosphorylation and ATF4 expression. However, the fact that the $\mathrm{PKR}^{-l-}$ mice do not show any change in the levels of eIF $2 \alpha$ phosphorylation (Fig. 7) suggests that there might be even more complex molecular mechanisms, in addition to eIF2 $\alpha$ phosphorylation, involved in the enhancement of learning and memory after PKR inhibition. Indeed, a recent detailed study supports the idea that IFN- $\gamma$-mediated selective reduction of GABAergic synaptic transmission is another potential mechanism that could also link decreased PKR activity to enhanced learning and memory (Zhu et al., 2011). IFN- $\gamma$ was increased in the hippocampus of $\mathrm{PKR}^{-/-}$mice, and genetic and pharmacological inhibition of PKR or decreased eIF2 $\alpha$ phosphorylation increased IFN- $\gamma$ translation and thereby linked PKR-dependent and eIF $2 \alpha$ phosphorylation-dependent expression of IFN- $\gamma$ (BenAsouli et al., 2002; Cohen-Chalamish et al., 2009; Zhu et al., 2011). However, the possibility that IFN- $\gamma$-mediated selective reduction of GABAergic synaptic transmission acts in concert with regulation of ATF4-dependent CREB-mediated transcription/translation and/or other mechanisms cannot be ruled out. For instance, BACE1 mRNA translation was reported to be controlled by eIF $2 \alpha$ phosphorylation (O'Connor et al., 2008) and, interestingly, the activation of PKR followed by an increase in eIF $2 \alpha$ phosphorylation, which impaired contextual fear memory, was also correlated with BACE1 expression (Jiang et al., 2010). Although the function of BACE1 in APP cleavage is known, its role in learning and memory consolidation is less clear 
(Ma et al., 2007; Jiang et al., 2010). Together, these findings show that PKR eIF2 $\alpha$ phosphorylation regulates several synaptic plasticity- and learning and memoryrelated proteins and pathways. Thus, further comprehensive studies, aimed to analyze at the levels of translational regulation and translated proteins, are required to understand how PKR inhibition enhances various forms of learning and memory.

In conclusion, we demonstrated that the dephosphorylation of eIF $2 \alpha$ is both correlated with and necessary for longterm cortex-dependent taste learning and memory formation. We presented evidence that pharmacological inhibition of PKR enhanced both positive and negative forms of long-term taste memory. In light of the findings that the activity of PKR is increased in several neurodegenerative diseases, including Alzheimer's disease models and agingrelated cognitive decline (Segev et al., 2013), and that PKR inhibition enhanced long-term memory storage, we suggest that PKR could be a potential target to improve cognition and treat cognitive dysfunction.

\section{References}

Abraham N, Stojdl DF, Duncan PI, Méthot N, Ishii T, Dubé M, Vanderhyden BC, Atkins HL, Gray DA, McBurney MW, Koromilas AE, Brown EG, Sonenberg N, Bell JC (1999) Characterization of transgenic mice with targeted disruption of the catalytic domain of the double-stranded RNA-dependent protein kinase, PKR. J Biol Chem 274:5953-5962. CrossRef Medline

Alberini CM (2011) The role of reconsolidation and the dynamic process of long-term memory formation and storage. Front Behav Neurosci 5:12. CrossRef Medline

Alberini CM, Milekic MH, Tronel S (2006) Mechanisms of memory stabilization and destabilization. Cell Mol Life Sci 63:999-1008. CrossRef Medline

Antion MD, Merhav M, Hoeffer CA, Reis G, Kozma SC, Thomas G, Schuman EM, Rosenblum K, Klann E (2008a) Removal of S6K1 and S6K2 leads to divergent alterations in learning, memory, and synaptic plasticity. Learn Mem 15:29-38. CrossRef Medline

Antion MD, Hou L, Wong H, Hoeffer CA, Klann E (2008b) mGluRdependent long-term depression is associated with increased phosphorylation of 66 and synthesis of elongation factor 1A but remains expressed in S6K-deficient mice. Mol Cell Biol 28:2996-3007. CrossRef Medline

Bando Y, Onuki R, Katayama T, Manabe T, Kudo T, Taira K, Tohyama M (2005) Double-strand RNA dependent protein kinase (PKR) is involved in the extrastriatal degeneration in Parkinson's disease and Huntington's disease. Neurochem Int 46:11-18. CrossRef Medline

Banko JL, Klann E (2008) Cap-dependent translation initiation and memory. Prog Brain Res 169:59-80. CrossRef Medline

Banko JL, Poulin F, Hou L, DeMaria CT, Sonenberg N, Klann E (2005) The translation repressor 4E-BP2 is critical for eIF4F complex formation, synaptic plasticity, and memory in the hippocampus. J Neurosci 25: 9581-9590. CrossRef Medline

Banko JL, Merhav M, Stern E, Sonenberg N, Rosenblum K, Klann E (2007) mean \pm SEM.
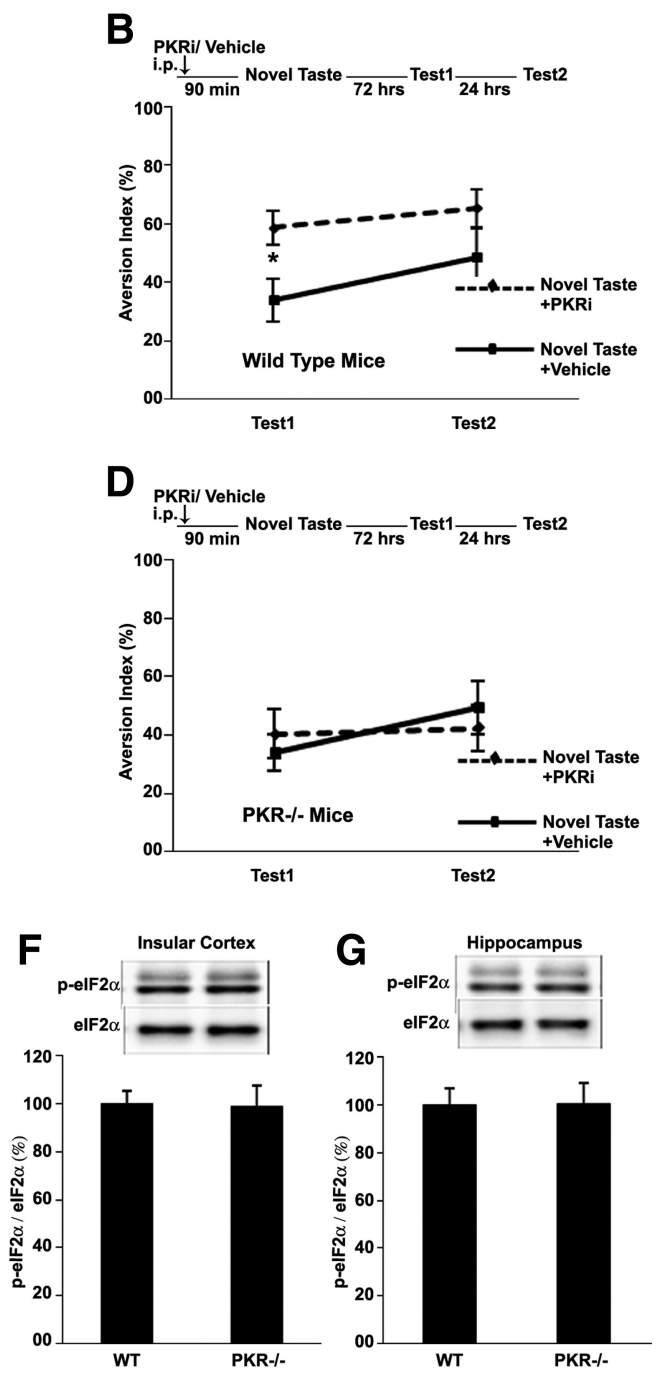

Figure 7. PKRi enhances novel taste and CTA memory in mice specifically via PKR inhibition. $A$, Systemic injection (i.p.) of PKRi enhanced CTA memory in wt mice compared with that of vehicle-injected mice $(n=8) .{ }^{*} p<0.05 .{ }^{* *} p<0.01 . \boldsymbol{B}$, Taste preference of wt

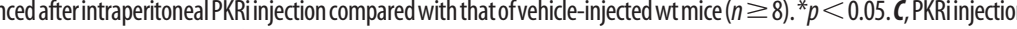

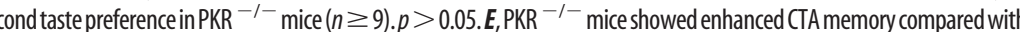
$\mathrm{KR}^{-1-}$ mice compared with that of control mice $(n \geq 8)$. $\boldsymbol{A}-\boldsymbol{E}$, Top diagrams represent the outline of the behavioral procedure. Data are

Behavioral alterations in mice lacking the translation repressor 4E-BP2. Neurobiol Learn Mem 87:248-256. CrossRef Medline

Barki-Harrington L, Elkobi A, Tzabary T, Rosenblum K (2009) Tyrosine phosphorylation of the 2B subunit of the NMDA receptor is necessary for taste memory formation. J Neurosci 29:9219-9226. CrossRef Medline

Bartsch D, Ghirardi M, Skehel PA, Karl KA, Herder SP, Chen M, Bailey CH, Kandel ER (1995) Aplysia CREB2 represses long-term facilitation: relief of repression converts transient facilitation into long-term functional and structural change. Cell 83:979-992. CrossRef Medline

Belelovsky K, Elkobi A, Kaphzan H, Nairn AC, Rosenblum K (2005) A molecular switch for translational control in taste memory consolidation. Eur J Neurosci 22:2560-2568. CrossRef Medline

Belelovsky K, Maroun M, Rosenblum K (2007) MAPK activation in the cortex is correlated with experimental setting. Neurobiol Learn Mem 88:58-64. CrossRef Medline

Belelovsky K, Kaphzan H, Elkobi A, Rosenblum K (2009) Biphasic activation of the mTOR pathway in the gustatory cortex is correlated with and necessary for taste learning. J Neurosci 29:7424-7431. CrossRef Medline

Ben-Asouli Y, Banai Y, Pel-Or Y, Shir A, Kaempfer R (2002) Human interferon- $\gamma$ mRNA autoregulates its translation through a pseudoknot 
that activates the interferon-inducible protein kinase PKR. Cell 108:221232. CrossRef Medline

Chen A, Muzzio IA, Malleret G, Bartsch D, Verbitsky M, Pavlidis P, Yonan AL, Vronskaya S, Grody MB, Cepeda I, Gilliam TC, Kandel ER (2003) Inducible enhancement of memory storage and synaptic plasticity in transgenic mice expressing an inhibitor of ATF4 (CREB-2) and C/EBP proteins. Neuron 39:655-669. CrossRef Medline

Cohen-Chalamish S, Hasson A, Weinberg D, Namer LS, Banai Y, Osman F, Kaempfer R (2009) Dynamic refolding of IFN- $\gamma$ mRNA enables it to function as PKR activator and translation template. Nat Chem Biol 5:896-903. CrossRef Medline

Costa-Mattioli M, Gobert D, Harding H, Herdy B, Azzi M, Bruno M, Bidinosti M, Ben Mamou C, Marcinkiewicz E, Yoshida M, Imataka H, Cuello AC, Seidah N, Sossin W, Lacaille JC, Ron D, Nader K, Sonenberg N (2005) Translational control of hippocampal synaptic plasticity and memory by the eIF2 kinase GCN2. Nature 436:1166-1173. CrossRef Medline

Costa-Mattioli M, Gobert D, Stern E, Gamache K, Colina R, Cuello C, Sossin W, Kaufman R, Pelletier J, Rosenblum K, Krnjević K, Lacaille JC, Nader K, Sonenberg N (2007) eIF2 phosphorylation bidirectionally regulates the switch from short- to long-term synaptic plasticity and memory. Cell 129:195-206. CrossRef Medline

Costa-Mattioli M, Sossin WS, Klann E, Sonenberg N (2009a) Translational control of long-lasting synaptic plasticity and memory. Neuron 61:10-26. CrossRef Medline

Costa-Mattioli M, Sonenberg N, Richter JD (2009b) Translational regulatory mechanisms in synaptic plasticity and memory storage. Prog Mol Biol Transl Sci 90:293-311. CrossRef Medline

Couturier J, Morel M, Pontcharraud R, Gontier V, Fauconneau B, Paccalin M, Page G (2010) Interaction of double-stranded RNA-dependent protein kinase (PKR) with the death receptor signaling pathway in amyloid beta (Abeta)-treated cells and in APPSLPS1 knock-in mice. J Biol Chem 285:1272-1282. CrossRef Medline

Dever TE (2002) Gene-specific regulation by general translation factors. Cell 108:545-556. CrossRef Medline

Dudai Y (2004) The neurobiology of consolidations, or, how stable is the engram? Annu Rev Psychol 55:51-86. CrossRef Medline

Elkobi A, Ehrlich I, Belelovsky K, Barki-Harrington L, Rosenblum K (2008) ERK-dependent PSD-95 induction in the gustatory cortex is necessary for taste learning but not retrieval. Nat Neurosci 11:1149-1151. CrossRef Medline

Gal-Ben-Ari S, Rosenblum K (2011) Molecular mechanisms underlying memory consolidation of taste information in the cortex. Front Behav Neurosci 5:87. CrossRef Medline

Gildish I, Manor D, David O, Sharma V, Williams D, Agarwala U, Wang X, Kenney JW, Proud CG, Rosenblum K (2012) Impaired associative taste learning and abnormal brain activation in kinase-defective eEF2K mice. Learn Mem 19:116-125. CrossRef Medline

Gkogkas C, Sonenberg N, Costa-Mattioli M (2010) Translational control mechanisms in long-lasting synaptic plasticity and memory. J Biol Chem 285:31913-31917. CrossRef Medline

Gutiérrez R, Rodriguez-Ortiz CJ, De La Cruz V, Núñez-Jaramillo L, BermudezRattoni F (2003) Cholinergic dependence of taste memory formation: evidence of two distinct processes. Neurobiol Learn Mem 80:323-331. CrossRef Medline

Harding HP, Novoa I, Zhang Y, Zeng H, Wek R, Schapira M, Ron D (2000) Regulated translation initiation controls stress-induced gene expression in mammalian cells. Mol Cell 6:1099-1108. CrossRef Medline

Hinnebusch AG (2000) Translational control of gene expression. (Sonenberg N, Hershey JWB, Mathews MB, eds), pp 185-243. New York: Cold Spring Harbor Laboratory.

Hoeffer CA, Cowansage KK, Arnold EC, Banko JL, Moerke NJ, Rodriguez R, Schmidt EK, Klosi E, Chorev M, Lloyd RE, Pierre P, Wagner G, LeDoux JE, Klann E (2011) Inhibition of the interactions between eukaryotic initiation factors $4 \mathrm{E}$ and 4G impairs long-term associative memory consolidation but not reconsolidation. Proc Natl Acad Sci U S A 108:3383-3388. CrossRef Medline

Huttner WB, Schiebler W, Greengard P, De Camilli P (1983) Synapsin I (protein I), a nerve terminal-specific phosphoprotein. III: its association with synaptic vesicles studied in a highly purified synaptic vesicle preparation. J Cell Biol 96:1374-1388. CrossRef Medline

Ingrand S, Barrier L, Lafay-Chebassier C, Fauconneau B, Page G, Hugon J (2007) The oxindole/imidazole derivative $\mathrm{C} 16$ reduces in vivo brain $\mathrm{PKR}$ activation. FEBS Lett 581:4473-4478. CrossRef Medline

Jammi NV, Whitby LR, Beal PA (2003) Small molecule inhibitors of the RNA- dependent protein kinase. Biochem Biophys Res Commun 308:50-57. CrossRef Medline

Jiang Z, Belforte JE, Lu Y, Yabe Y, Pickel J, Smith CB, Je HS, Lu B, Nakazawa K (2010) eIF2alpha phosphorylation-dependent translation in CA1 pyramidal cells impairs hippocampal memory consolidation without affecting general translation. J Neurosci 30:2582-2594. CrossRef Medline

Johansen JP, Cain CK, Ostroff LE, LeDoux JE (2011) Molecular mechanisms of fear learning and memory. Cell 147:509-524. CrossRef Medline

Kaphzan H, O'Riordan KJ, Kile KP, Levenson JM, Rosenblum K (2006) NMDA and dopamine converge on the NMDA-receptor to induce ERK activation and synaptic depression in mature hippocampus. PLoS One 1:e138. CrossRef Medline

Kaphzan H, Doron G, Rosenblum K (2007) Co-application of NMDA and dopamine induce rapid translation of RSK2 in the mature hippocampus. J Neurochem 103:388-399. CrossRef Medline

Kelleher RJ 3rd, Govindarajan A, Tonegawa S (2004) Translational regulatory mechanisms in persistent forms of synaptic plasticity. Neuron 44:59-73. CrossRef Medline

Klann E, Dever TE (2004) Biochemical mechanisms for translational regulation in synaptic plasticity. Nat Rev Neurosci 5:931-942. CrossRef Medline

Ma H, Lesné S, Kotilinek L, Steidl-Nichols JV, Sherman M, Younkin L, Younkin S, Forster C, Sergeant N, Delacourte A, Vassar R, Citron M, Kofuji P, Boland LM, Ashe KH (2007) Involvement of-site APP cleaving enzyme 1 (BACE1) in amyloid precursor protein-mediated enhancement of memory and activity-dependent synaptic plasticity. Proc Natl Acad Sci U S A 104:8167-8172. CrossRef Medline

Nader K, Hardt O (2009) A single standard for memory: the case for reconsolidation. Nat Rev Neurosci 10:224-234. CrossRef Medline

O'Connor T, Sadleir KR, Maus E, Velliquette RA, Zhao J, Cole SL, Eimer WA, Hitt B, Bembinster LA, Lammich S, Lichtenthaler SF, Hébert SS, De Strooper B, Haass C, Bennett DA, Vassar R (2008) Phosphorylation of the translation initiation factor eIF2 increases BACE1 levels and promotes amyloidogenesis. Neuron 60:988-1009. CrossRef Medline

Paquet C, Bose A, Polivka M, Peoc'h K, Brouland JP, Keohane C, Hugon J, Gray F (2009) Neuronal phosphorylated RNA-dependent protein kinase in Creutzfeldt-Jakob disease. J Neuropathol Exp Neurol 68:190198. CrossRef Medline

Peel AL, Bredesen DE (2003) Activation of the cell stress kinase PKR in Alzheimer's disease and human amyloid precursor protein transgenic mice. Neurobiol Dis 14:52-62. CrossRef Medline

Peel AL, Rao RV, Cottrell BA, Hayden MR, Ellerby LM, Bredesen DE (2001) Double-stranded RNA-dependent protein kinase, PKR, binds preferentially to Huntington's disease (HD) transcripts and is activated in HD tissue. Hum Mol Genet 10:1531-1538. CrossRef Medline

Rosenblum K (2008) Conditioned taste aversion and taste learning: molecular mechanisms. Learning and memory: a comprehensive reference, pp 217-234. Amsterdam: Elsevier.

Rosenblum K, Meiri N, Dudai Y (1993) Taste memory: the role of protein synthesis in gustatory cortex. Behav Neural Biol 59:49-56. CrossRef Medline

Rosenblum K, Berman DE, Hazvi S, Lamprecht R, Dudai Y. (1997) NMDA receptor and the tyrosine phosphorylation of its $2 \mathrm{~B}$ subunit in taste learning in the rat insular cortex. J Neurosci 17:5129-5135. Medline

Schumann J, Yaka R (2009) Prolonged withdrawal from repeated noncontingent cocaine exposure increases NMDA receptor expression and ERK activity in the nucleus accumbens. J Neurosci 29:6955-6963. CrossRef Medline

Segev Y, Michaelson DM, Rosenblum K (2013) ApoE $\varepsilon 4$ is associated with eIF $2 \alpha$ phosphorylation and impaired learning in young mice. Neurobiol Aging 34:863-872. CrossRef Medline

Sonenberg N, Dever TE (2003) Eukaryotic translation initiation factors and regulators. Curr Opin Struct Biol 13:56-63. CrossRef Medline

Sonenberg N, Hinnebusch AG (2009) Regulation of translation initiation in eukaryotes: mechanisms and biological targets. Cell 136:731-745. CrossRef Medline

Takei N, Kawamura M, Hara K, Yonezawa K, Nawa H (2001) Brain-derived neurotrophic factor enhances neuronal translation by activating multiple initiation processes: comparison with the effects of insulin. J Biol Chem 276:42818-42825. CrossRef Medline

Vattem KM, Wek RC (2004) Reinitiation involving upstream ORFs regu- 
lates ATF4 mRNA translation in mammalian cells. Proc Natl Acad Sci U S A 101:11269-11274. CrossRef Medline

Yefet K, Merhav M, Kuulman-Vander S, Elkobi A, Belelovsky K, JacobsonPick S, Meiri N, Rosenblum K (2006) Different signal transduction cascades are activated simultaneously in the cortex and hippocampus following novel taste learning. Eur J Neurosci 24:1434-1442. CrossRef Medline
Zhu PJ, Huang W, Kalikulov D, Yoo JW, Placzek AN, Stoica L, Zhou H, Bell JC, Friedlander MJ, Krnjević K, Noebels JL, Costa-Mattioli M (2011) Suppression of PKR promotes network excitability and enhanced cognition by interferon- $\gamma$-mediated disinhibition. Cell 147: 1384-1396. CrossRef Medline 